\title{
Conditions for economic prosperity: transforming residential neighbourhoods
}

\author{
Tina M. Barton
}

In every city there are stories of neighbourhood successes and failures. Why do some neighbourhoods excel at attracting and sustaining economic activity, whereas others fail? What conditions would best assist a neighbourhood in enhancing its economic prosperity? This paper examines the connection between transit-oriented development and economic impact, with a comparison of bus versus light-rail transit implications. "Complete streets" and mixed-use models of development, evolving lifestyle preferences, and related opportunities for community economic development are explored. Communities, municipalities and neighbourhood business associations can draw upon these models, practices and strategic considerations to guide their planning for future economic success.

Keywords: Suburban economic development, neighbourhood revitalization, transitoriented development, mixed-use neighbourhoods, community placemaking.

\section{Introduction}

There will always be inequality between neighbourhoods of a city. Change is constant: homeowners come and go, businesses open, change hands, close, start anew. Some neighbourhoods become richer over time, others poorer or stagnant. But why? Why is it that some neighbourhoods excel at attracting business, commerce and crowds, whereas others fail? Is there one critical factor that makes the difference above all others; and if so, what is that key element?

This paper answers these questions by examining studies, literature reviews, surveys and articles, primarily from North America, but also with some reference to the United Kingdom (U.K.). The paper sets the stage with an overview of historic city development, followed by the impact of the automobile in the $20^{\text {th }}$ century on movement and city design. Lifestyle preferences have since continued to evolve, further impacting the neighbourhood composition within our cities.

Given the reliance on vehicles to move around cities, a quick assumption is that connectivity in and out of a neighbourhood - whether by personal vehicle or public transportation - is one of the biggest contributing factors to neighbourhood appeal and associated economic activity. But taking it a step further, among the various transportation modes, it is reasonable to question whether there is a particular transit mode that delivers the most economic value. This paper will investigate this, and ultimately highlight the conditions that make neighbourhoods more economically viable. 


\section{North America and the United Kingdom}

When cities were first being intentionally designed in North America, the predominant thinking behind "Anglo-American" town planning was to keep commercial and residential zones separate, reportedly to minimize the spread of disease (Greed, 2010). From the start, this separation required people to travel to their external places of work. With railways being a key mode of transit at the time, most settlements developed close to railway lines, and much travel happened by train.

The arrival and ensuing mass ownership of the automobile in the era of World War II and beyond reshaped urban living in North America significantly. As car ownership accelerated after World War II, trains became far less significant for transportation. The freedom of the automobile meant people no longer needed to live near railway lines or stations, instead the postwar "Baby Boomer" generation migrated to the suburbs, where more land was available and at cheaper prices (Brancheau, Wharton, \& Kamalov, n.d.). Baby Boomers' children grew up and moved out even farther into the suburbs. The result was the unimpeded sprawl of "bedroom communities", as neighbourhoods continued to push outwards in pursuit of the dream of the single family home, leading to what has been coined the "edgeless city" (Duany, Plater-Zyberk, \& Speck, 2000; Garreau, 1992; Lang, 2003, cited in Griffiths, Vaughan, Haklay, \& Jones, 2008). Increasingly in North America, clusters of retail outlets (commonly known as strip malls) were developed alongside major highways and transit routes, placing greater emphasis on car-oriented retail (Rowley, 2006; Whitehand \& Carr, 2001, cited in Griffiths et al., 2008). This led to further decentralization and sprawl of commercial zones away from residential areas.

Development in the U.K. showed the same preference for settling around rail lines, however geographical constraints, such as mountainous terrain and space limitations, prevented urban sprawl from happening to the same extent that it did in North America. Instead, the economic success of the U.K. "High Street" - a street featuring a concentration and variety of small local shops with easy pedestrian access (Rowley 2006; Whitehand and Carr 2001, cited in Griffiths et al., 2008) meant that U.K. High Streets persisted for longer than their North American "Main Street" counterpart.

High Streets were typically located close to residential areas, which also meant less automobile dependence and more walkability in the U.K. compared to North America. Some neighbourhoods intentionally resembled the "living street" model, designed to be a social space, with the interests of pedestrians and cyclists primarily in mind. Although such streets were still available to automobiles, vehicle traffic does not receive the same priority, which distinguished "living streets" from their "complete streets" counterparts in North America (U.S. Environmental Protection Agency, 2014). The complete streets model has more recently been gaining popularity in North America, as consumers show increasing interest in shopping local and integrating exercise (walking and biking) into their commutes.

\section{Revitalizing urban centres in North America}

Although historically it has been customary to separate residential areas from shopping and business zones in North America, "Baby Boomers", "Millennials", and those born in between, 
are now showing a preference for living in transit-oriented, mixed-use communities that offer more walkable and connected lifestyles (D'Hooghe, 2012). This model is known as "New Urbanism" and represents a return to the principles of how cities and towns were built in the last several centuries: walkable streets, housing and shopping in close proximity, and accessible public spaces. In other words, "human-scaled urban design" (Congress for the New Urbanism n.d.). Alternatives to automobile dependency have been especially important in recent years as tougher economic conditions since the 2008 global recession have impacted job availability and increased unemployment rates among youth; commonly cited as a reason for lower car ownership rates among Millennials as covered in publications including The Atlantic (Thompson, D. \& Weissmann, J., 2012) and Maclean's (Sorensen, C., 2015). Accompanied by the rise of the "sharing economy" with car-sharing services such as Zipcar and Uber, these factors have diverted some interest away from personal vehicle ownership and toward public transit systems, walking or biking. Research over the past decade has evaluated the effect of car sharing on vehicle kilometers travelled and vehicle ownership, and often found that it reduces both (Martin, E., \& Shaheen, S., 2011). It is logical to assume that people stay closer to home when they do not have a vehicle. This represents opportunities for neighbourhoods to remodel themselves into more mixed-use areas (commercial and residential). The following explores the conditions required to support a new economy such as this in formerly residential neighbourhoods.

\section{Transit-oriented development}

Transit-oriented development maximizes the amount of residential, business and leisure spaces within walking distance of public transport. The transit station or stop is positioned centrally within a high-density, mixed-use area, and the street design is friendly to pedestrians, through sidewalks, smaller block sizes, and even reduced space given to automobile traffic Transit-oriented development clearly requires designated transit space and infrastructure. This is why "Middle Ring" suburbs - those situated between the downtown and outlying residential suburbs - represent a strong opportunity for attracting transit investments and capturing economic interest among the business community (D'Hooghe, 2012). Middle Ring suburbs afford the space for new development, and are already located in a transit corridor, close to highways and public transit routes.

The advantage that public transit offers to economic prosperity over private vehicle use is "agglomeration", which in simple terms means a mass of people in the same place. Planning scholar Daniel Chatman of the University of California at Berkeley, and planner Robert Noland of Rutgers University, conducted a study which found that every time a metro area added about four seats to public transit per 1,000 residents, the central city ended up with 320 more employees per square mile; an increase of 19 per cent (Jaffe, 2013). Agglomeration brings a larger pool of workers and customers into the area, so neighbourhoods that can support agglomeration through access to public transit will have better economic success than those that cannot.

While agglomeration can be achieved through bus or light-rail systems, light-rail systems offer many more associated economic benefits to an area over the bus. A report on light rail transit (LRT) for the City of Hamilton (Canada) in 2010 found that investment in rapid transit - 
particularly rail systems - has a positive impact on property values in the general area of a new rapid transit line, especially areas close to transit stations. The study showed that having an LRT station nearby can add as much as six per cent to the value of residential properties in the area, and as much as 14 per cent to commercial properties (Metrolinx, 2010). In addition, when projecting the anticipated transportation user benefits, as well as financial, environmental, economic development and socio-community impacts over a 30-year period, the report anticipated that the implementation of an LRT system would return significant dividends in both employment and economic impact compared to a bus rapid transit (BRT) system. The report projected a return of $\$ 852$ million in transportation benefits to LRT riders, compared to just $\$ 313$ million for BRT riders. The report also estimated that an LRT system would generate approximately 5,793 person-years of employment (including both direct and indirect impacts) compared to just 1,837 person-years of employment for BRT. Further, that during this time, the Gross Domestic Product (GDP) would be \$487.5 million for LRT compared to \$129.4 million for BRT (Metrolinx, 2010).

While an LRT system is clearly more expensive and time-consuming to establish, it also generates substantial economic benefits through its need for materials, services and employment. Note: The City of Hamilton also considered a third option, a phased approach that would delay the development of some portions of an LRT line and stations. This option would defer some of the capital and ongoing operating costs but still generate relatively strong employment, income and construction GDP effects. Nonetheless, the report noted that opportunities for investment attraction, economic growth and increased property values would be constrained compared to the full LRT option. As of mid-2016, the City of Hamilton had decided to proceed with a system that most closely resembled the full LRT option (Craggs, 2016).

The appeal of LRT is also that proximity to this particular type of transit presents new and expanded opportunities for businesses in the area. The committed infrastructure required for an LRT system signals to the community a longer-term existence of this transit mode, which in turn introduces a broader customer and workforce base. In the United States, a report on the economic impact of transit for the Transportation Research Board found that the most significant development and new employment opportunities occurred after new transit facilities were opened in previously underserviced areas (Transportation Research Board, 2016). However, this alone does not bring economic success to a neighbourhood. A supportive business community and open zoning rules that enable existing spaces to be transformed for new uses are also very important for allowing economic development to flourish. Finally, proximity to public transit often leads to higher home values and rents, which has a multiplying economic benefit (Wardrip 2011, cited in Zuk, Bierbaum, Chapple, Gorska, Loukaitou-Sideris, Ong \& Thomas, 2015). The downside of this increasing wealth in the area - also known as "gentrification" (as per the Merriam-Webster definition) - is that lower income residents may no longer be able to afford to live in their area, which can lead to social/class exclusivity, reduced population diversity, and a loss of authenticity. These issues will be further elaborated in the "criticisms" section of this paper. 


\section{Creating a sense of place}

Transit aside, particular areas of a city appeal to people when they possess a distinct identity and become a destination in their own right. There are many ways to develop a neighbourhood identity: landscape and heritage architecture, a natural geographic feature (such as a mountain or park) could be leveraged to attract people, or perhaps through a sports complex or music hub. Whatever the "draw", it is important that it be unique enough to attract outsiders, and scalable to be able to accommodate a large number of people. That said, in the case of nature-related attractions, it is important that planners and developers do not allow too much or too rapid development to threaten or overtake this once desirable feature. Such placemaking requires support and leadership from the local government, business and residential community.

Another factor critical for economic success is density. It is important to have sufficient density of residents (and visitors to the neighbourhood) to be able to support commerce in the area. However, for a neighbourhood to truly develop a recognized identity and become known for a key landmark or service, it needs to possess a large enough presence in this area. Using restaurants and culinary attractions as an example, D'Hooghe (2012) suggested that in order to create a compelling "hub" effect, at least three restaurants are needed in an area, and that having five or more would be even more ideal. He also championed establishing "anchor tenants" that could safely be relied upon to generate significant customer traffic. D'Hooghe highlighted the supermarket as a proven option that generates significant ongoing foot traffic, delivering return on investment for the store and surrounding area.

Mixed-use buildings that appeal to a range of tenants and can accommodate a broad range of uses are also likely to yield more economic success. A good example is a mid-rise building that offers retail and public facilities on the ground floor, and housing above. Equally important is the ability for a building or space to be adaptable - in terms of construction, reconfiguration, and zoning permits - as needs change over time.

\section{"Complete streets" stimulate the economy}

Retail districts that accommodate cyclists and pedestrians can see significant economic impacts too. Such streets are known as "complete streets" because they integrate the needs of all road users in planning, design, construction, operation and maintenance (Transportation Association of Canada, 2015). In Mountain View, California, the addition of space for sidewalk cafes and a street redesign to become more pedestrian friendly was followed by private investment of $\$ 150$ million, including residential, retail and offices (Smart Growth America, 2012).

Conversely, areas that do not afford access and comfort to pedestrians and cyclists will miss out on economic opportunities. A Toronto study showed that local businesses underestimated the proportion of their customers who arrived on foot. This March 2014 survey found that most of the surveyed visitors had arrived on foot (46 per cent) - despite low temperatures and inclement weather - and that far more visitors took public transit than drove: 32 per cent compared to 19 per cent (Toronto Foundation, 2016). In another 2014 consultation, "Yonge Love", conducted by the Downtown Yonge Business Improvement Area, Torontonians reinforced their preference for "human-scale, walkable neighbourhoods" that saw fewer cars in Downtown Yonge. When 
participants chose from a list of possible changes to Yonge Street, their highest priority was pedestrian-only weekends (17 per cent). Sixteen per cent wanted to see more bike lanes, and 15 per cent wider sidewalks (Toronto Foundation, 2016). Customers are voicing their preference for complete streets and a return to walkable shopping areas, with economic returns showing to follow.

\section{Serving local and niche needs}

People will shop in their local area if the services are there. In Orléans, a neighbourhood on the eastern outskirts of Ottawa (Canada), the Heart of Orléans Business Improvement Association (BIA) found that 67 per cent of residents' daily trips that began in the community stayed in the community - the second highest rate in Ottawa. The reason cited for this was the increasing multi-use composition of the area, with its balance of homes, schools, services, shopping and recreation (Heart of Orléans BIA, 2014). The BIA surveyed the consumer and business community to determine why people chose (or not) to shop within the BIA district. The surveys revealed a preference for residents of the area to do their retail shopping just outside of the BIA district, in the nearby area where the big box stores were located. However, when it came to other services and needs, residents preferred to shop locally within the BIA area. The main draws were for restaurants (55 per cent), special events (40 per cent), and health/exercise facilities (40 per cent) (Heart of Orléans BIA, 2014). These findings are important as they show the perceived value proposition of the BIA area, which provides guidance for the BIA in regard to its identify, (re)branding initiatives, and range of businesses.

In another Ottawa neighbourhood, a 2015 survey undertaken by the Wellington West BIA showed that more than half of the participating customers (61 per cent) lived in the area and shopped in the area regularly, with about 27 per cent visiting three to four times per week. Almost half of the shoppers (41 per cent) were visiting more than five times per week (Lam \& Frojmovic, 2015). Wellington West is situated within a popular neighbourhood a few kilometres west of downtown and has seen significant residential growth over the past six years, which the business community hopes to match. In the same report, the BIA raised the need to consider whether the businesses alongside each other and clustered around intersections were compatible or competitive. The BIA also questioned their members' participation rate in the many community events in the area, which provide opportunities for local businesses to further develop relationships. Thirdly, the BIA observed that 61 per cent of businesses were closed on Sunday. This signifies greater sales opportunities for businesses that choose to be open on Sundays. While this paper has devoted much time to making the case for transit-oriented and walkable neighbourhoods to enhance economic prosperity, it is clear there are other offerings and changes that individual businesses can apply to make themselves more attractive and available to a larger customer base. BIAs should do their part to educate and encourage more of their member-businesses to make such changes if the need is apparent among their resident client base.

City planners, policy makers and developers also have a role to play in helping neighbourhood economic activity to flourish. For example, developers could make more office and retail space available to make it possible for employment hubs and small businesses to flourish, generating opportunities for local residents to earn income and similarly spend it in the area. Cities can also 
adjust permit policies to encourage the likes of street truck vendors, which allows smaller businesses to thrive and serve niche needs without facing high overhead rent or property costs. This can have significant economic and social impact, including enhancing the culture of the area.

\section{Criticisms of Complete Streets and New Urbanism}

No model is perfect and it would be remiss of this paper if it did not mention criticisms and weaknesses of the complete streets, transit-oriented development and New Urbanism models. Complete streets have been criticized for their contribution to gentrification, where the attraction of businesses and light rail raises property prices, pushing away poorer, immigrant and marginalized populations (Zavestoski \& Agyeman, 2015). Another criticism is that by encouraging alternate modes of transport to the automobile, complete streets can increase trip duration as it typically takes longer to walk, bike or take public transit than it does to drive a private vehicle (Moore \& Taylor, 2013). However, because the complete streets model also encourages greater system connectivity, the reverse argument could also be made that complete streets have the potential to decrease trip duration.

While this paper has praised the advantages to riders, homeowners, and local businesses when a neighbourhood introduces an LRT system, the prohibitive costs and barriers to entry cannot be ignored. The significant capital investment required to support the introduction of an LRT system is dependent, among other factors, on the city council's access to credit and external funding, and interest rate conditions. Further, the high costs of introducing an LRT system typically requires a critical mass of ridership in place before such investment can be contemplated. In many cases, this means a neighbourhood starts out with a BRT and then considers the costs and benefits of converting the transit system to LRT, as the City of Hamilton did. It is not quick, easy or cheap to introduce LRT to a neighbourhood, and neighbourhoods with low public transit ridership are unlikely to attract support and financing for an LRT system.

As for New Urbanism, this model has been criticized for creating "inauthentic" neighbourhoods by introducing architectural features from elsewhere in attempt to make urban suburbs resemble country towns - the faux white picket fence, for example (DeWolf, 2002). In some cases, New Urbanism has also failed in its goal of fostering stronger community life. The concept behind New Urbanism is to create social spaces that bring people together, which is why property lots are smaller, houses closer to the street (with garages tucked away at the rear of the house), and sidewalks plentiful, all to enhance opportunities for interaction (Moore \& Taylor, 2013). New Urbanism likewise supports the "Main Street" concept of a concentration of retail services and restaurants where people can congregate. However, when New Urbanism towns continue to separate commercial and residential zones, these towns fail in their New Urbanism goal of creating a stronger social fabric and making communities more self-sufficient.

Critics also argue that New Urbanism ignores a preference for privacy over community, and convenience over craftsmanship of homes. Some issues with this argument, however, are that its central premise does little to prevent the problem of urban sprawl, and that it contradicts other studies that have revealed a more communal willingness among the Millennial generation (D'Hooghe, 2012). 


\section{Conclusion}

As articulated throughout this paper, the economic success of a neighbourhood is influenced by a number of factors. Transit-oriented, mixed-use, "complete streets" conditions are all important for neighbourhoods wishing to generate economic prosperity. Proximity to highways and public transit (especially rapid transit) is needed to bring people into the area and support agglomeration. Transit-oriented development has been shown to increase agglomeration, attract investment, increase commercial and employment opportunities and, particularly in the case of light rail, increase property values. Meanwhile, mixed-use development that contains low-risk, high-return anchor tenants, and offers the flexibility for the space or building to be converted for different uses in future, also influences economic success. To enhance economic prosperity, local BIAs should review whether their business mix is complementary or competitive, and create conditions to support a complementary composition. Local businesses should also maximize their participation in community events to build relationships and expand their client base. To enhance opportunities for such social interaction, the New Urbanism and complete streets models both encourage neighbourhoods to be developed with the human scale in mind, creating social spaces that are accessible to pedestrians and cyclists, as well as automobiles, particularly as people show preference for alternatives to car dependency. Regarding transit systems, lightrail has shown to generate the greatest economic opportunities through direct and indirect impacts. This means, ironically, that some communities in North America are experiencing a return to rail, after shifting away from that very model under the guise of "progress" close to a century earlier.

\section{Author biography}

Tina Barton was born and raised in New Zealand. Following the completion of her university studies (Bachelor of Arts degree in Political Science and English Literature; Graduate Diploma of Journalism), she travelled the world extensively before settling in Ottawa, Canada. She has held partnership, communications, and community-building positions across the private, nonprofit, and media sectors. Tina is interested in sustainable urban planning, and leveraging economic opportunities for environmental, social, and community good. Tina is completing her Certificate in Economic Development with the University of Waterloo.

\section{References}

Brancheau, J., Wharton, A., \& Kamalov, F. (n.d.). The History of the Automobile. Retrieved from http://13d.cs.colorado.edu/systems/agentsheets/New-Vista/automobile/

Congress for the New Urbanism (n.d.). What's New Urbanism? Retrieved from https://www.cnu.org/resources/what-new-urbanism

Craggs, S. (2016). 10 answers to burning questions about LRT in Hamilton. Retrieved from http://www.cbc.ca/news/canada/hamilton/news/lrt-questions-1.3586590 
D'Hooghe, A. (2012). Toward a Development Model for the Middle Ring Suburbs. Retrieved from http://www.naiop.org/en/Research/Our-Research/Reports/A-Development-Modelfor-the-Middle-Ring-Suburbs.aspx

DeWolf, C. (2002). Why New Urbanism Fails. Retrieved from http://www.planetizen.com/node/42

Goodling, E. \& Herrington, C., (2014). Reversing Complete Streets Disparities: Portland's Community Watershed Stewardship Program. In J. Agyeman \& S. Zavestoski (Eds.),

Incomplete Streets: Processes, Practices, and Possibilities (p. 180). New York: Routledge. Retrieved from http://www.academia.edu/29078513/Reversing_Complete_Streets_Disparities_Portland_ s_Community_Watershed_Stewardship_Program.

Gentrification. (n.d.). In Merriam-Webster online. Retrieved from http://www.merriamwebster.com/dictionary/gentrification

Greed, C. (2010). Non-Sexist City. In R. Hutchison (Ed.), Encyclopedia of Urban Studies (p. 571). Thousand Oaks, California: SAGE Publications.

Griffiths, S., Vaughan, L., Haklay, M., \& Jones, C. E. (2008). The Sustainable Suburban High Street: A Review of Themes and Approaches. Retrieved from http://citeseerx.ist.psu.edu/viewdoc/download?doi=10.1.1.599.7363\&rep=rep1\&type=pdf

Heart of Orléans BIA (2014). Market Research Project [PDF].

Jaffe, E. (2013). Public Transit Is Worth Way More to a City Than You Might Think. Retrieved from http://www.citylab.com/work/2013/08/public-transit-worth-way-more-city-youthink/6532/

Lam, J., \& Frojmovic, M. (2015). Census of the Wellington West BIA: Final Report [PDF]

Martin, E., \& Shaheen, S. (2011). The Impact of Carsharing on Public Transit and NonMotorized Travel: An Exploration of North American Carsharing Survey Data. In Energies 2011, 4, 2094-2114. Retrieved from http://sfpark.org/wpcontent/uploads/carshare/The_Impact_of_Carsharing_on_Public_Transit_and_NonMotorized_Travel.pdf

Metrolinx (2010). Hamilton King-Main Rapid Transit Benefits Case. Retrieved from http://www.metrolinx.com/en/regionalplanning/projectevaluation/benefitscases/Benefits_ Case-Hamilton.pdf 
Moore, T., \& Taylor, P. (2013). White Paper on the Economics of Complete Streets. Retrieved from https://sccrtc.org/wp-content/uploads/2013/08/2013-complete-streetswhitepaper.pdf

Smart Growth America (2012). Economic Development: Complete Streets Stimulate the Local Economy. Retrieved from https://www.smartgrowthamerica.org/app/legacy/documents/cs/factsheets/cseconomic.pdf

Sorensen, C. (2015, January 17). Young and Carless. Maclean's. Retrieved from http://www.macleans.ca/economy/business/young-and-carless/

Thompson, D. \& Weissmann, J. (2012, September). The Cheapest Generation. The Atlantic. Retrieved from https://www.theatlantic.com/magazine/archive/2012/09/the-cheapestgeneration/309060/

Toronto Foundation (2016). Toronto's Vital Signs 2016 Report. Retrieved from http://torontosvitalsigns.ca/main-sections/getting-around/

Transportation Association of Canada (2015). Complete Streets: Policy and Practice in Canada Retrieved from http://www.tac-atc.ca/sites/tac-atc.ca/files/site/doc/Bookstore/briefingfinal-e-jan2015.pdf

Transportation Research Board (2016). Report 186 (Pre-Publication Draft): Economic Impact Case Study Tool for Transit. Retrieved from http://onlinepubs.trb.org/Onlinepubs/tcrp/tcrp_rpt_186.pdf

U.S. Environmental Protection Agency (2009). Implementing Living Streets: Ideas and Opportunities for the City and County of Denver. Retrieved from https://www.epa.gov/sites/production/files/201404/documents/sgn_website_2014_final_3_20_14.pdf

Wayland, S. (2011). The Impact of Light Rail Transit on Low-Income Households and Neighbourhoods. Retrieved from https://www.raisethehammer.org/article/1479/the_impact_of_light_rail_transit_on_lowincome_households_and_neighbourhoods

Zuk, M., Bierbaum, A., Chapple, K., Gorska K., Loukaitou-Sideris, A., Ong, P., \& Thomas, T. (2015). Gentrification, Displacement and the Role of Public Investment: A Literature Review. Retrieved from http://www.frbsf.org/community-development/files/wp201505.pdf 